\title{
Mortality Rate of Fish Seeds (Labeo rohita) During Traditional Transportation System in the Northwest Bangladesh
}

\author{
M. N. Islam ${ }^{1 *}$ and M. A. Hossain ${ }^{2}$ \\ ${ }^{1}$ Graduate School of Science and Technology, Biogeochemistry Laboratory, Shizuoka University, \\ 836 Ohya, Suruga-ku, Shizuoka 422-8529, Japan \\ ${ }^{2}$ Department of Zoology, University of Rajshahi, Rajshahi-6205, Bangladesh
}

Received 12 May 2012, accepted in final revised form 21 January 2013

\begin{abstract}
This investigation deals with the mortality rate of fish seeds (Labeo rohita) during traditional transportation system; to evaluate the effects of loading density with time scale under different water medium; temperature effect with relation to fry size and oxygen consumption; and the effect of saline water bath before transportation. Mortality rates were significantly increased with time scale and loading density under different water medium. Higher mortality was observed at $400 \mathrm{~g} \mathrm{~L}^{-1}$ loading density (river water $82 \%$, pond water $70 \%$ and tubewell water $67.5 \%$ ) than at $200 \mathrm{~g} \mathrm{~L}^{-1}$ and $300 \mathrm{~g} \mathrm{~L}^{-1}$ loading density after $24 \mathrm{~h}$. Oxygen consumption rate increased significantly with increasing temperature and decreased significantly with increasing fry body weight. Therefore, mortality rate could decrease $(22 \%)$ if fish fry are bathed in saline water before journey and tubewell water can be use as a medium for long distance transportation.
\end{abstract}

Keywords: Mortality; Fish seeds; Oxygen consumption; Transportation.

@ 2013 JSR Publications. ISSN: 2070-0237 (Print); 2070-0245 (Online). All rights reserved.

doi: http://dx.doi.org/10.3329/jsr.v5i2.10572 J. Sci. Res. 5 (2), 383-392 (2013)

\section{Introduction}

Generally the fry trading season starts in April and continues until the end of September in Bangladesh. During the fry trading season between 800 to 900 traders from all parts of the region purchase fingerlings every night from middlemen in the northwest region of Bangladesh. Nevertheless, mortality is the major problem of our traditional transportation system of fish fry. In Bangladesh, fish seed production hatcheries are typically situated far away from fish rearing ponds. The traditional fish seed transportation methods result in heavy mortality due to accumulation of toxic wastes such as ammonia, decrease in $\mathrm{pH}$ due to increase of carbon dioxide $\left(p \mathrm{CO}_{2}\right)$, depletion of oxygen in the water, thermal tolerance [1], hyperactivity, stress and tiredness of the fry and infection contracted during transportation [2].

\footnotetext{
*Corresponding author: mn_islamzoolru@yahoo.com
} 
Freshwater aquaculture depends mainly on carp culture and proved sustainable over the years [3]. However many technical problems arise in the production of fish seed either in the pond or hatchery system. Fish seeds are very sensitive to handling stress $[4,5]$. Mass mortalities were often encountered by fry gatherers and fish farmers during transport but also during temporary storage until disposal and in nursery rearing [6]. The high mortalities encountered during the first 3 weeks of nursery rearing of these spawns were attributed to poor larval condition caused by inadequate transport technology. Handling stresses primarily enhanced metabolic rate of the fry, low oxygen capacity and rapid accumulation of toxic metabolites such as ammonia and carbon dioxide in a closed system are important causative factors to fish seeds mortalities during transportation [7-10]. Metabolic activities are dependents on acclimation temperature, period and species [11, 12]. Favorable temperatures can be predictable based on the relationship between oxygen consumption and acclimation temperature [13]. Several studies have been conducted to consider some fundamental physiological requirements of fish seeds including temperature, $\mathrm{pH}, \mathrm{DO}$, and water quality during transportation. Temperature is an important factor that affects all physiological processes in ectotherms such as food intake, metabolism, nutritional efficiency and growth [14-16]. Therefore, low temperature [17, 18], starving the fry before load [19-24] and use of oxygen in the bags and various anesthetics were used for reduction of fry movements [25-27].

Carp fish is a high valued cultured fish in all over the Bangladesh. Most of the fish seeds are shipped by the land transport in open containers. Traditionally practice consists of placing the fish fry in aluminum vessels $(30 \mathrm{~L})$ filled with water and continuously aerating the water manually during transportation. Due to poor transportation medium of the illiterate, half-educated and unskilled fry traders, the mortality rate of fry is on the rise as a result the icthyo-biodiversity of the country is now on the verge of extinction. Therefore, the present study was conducted to determine the mortality rates and stress level of fish seeds (Labeo rohita) under traditional conditioning process. For that we design simulation experiment to evaluate loading density and duration of transport under different water medium; effect of temperature with relation to fry size and oxygen consumption rates; and the effect of saline water bath before transportation.

\section{Material and Methods}

\subsection{Conditioning and preparation for transportation}

Fish seeds (fingerlings, 4-10 cm) were obtained from the Anando Matshaw Hatchery, Rajshahi, Bangladesh. For simulation purposes, the fingerlings were conditioned following typical procedures practiced by nursery. First, the fingerlings were transferred from the nursery to the conditioning pond (locally called pakai pond; $40 \times 30 \mathrm{~m}$ ). After 24 $\mathrm{h}$ in the pakai pond, the fingerlings were caught and kept in hapas with manual aeration (water splashing) for 30 min every morning for 3-4 days. After $30 \mathrm{~min}$ of aeration, the fingerlings were released back into the pakai pond. The fingerlings were fed wet mustard 
oil cake daily at $2 \%$ body weight, and artificial feeding was stopped $12-24 \mathrm{~h}$ before harvesting into the transport vessels.

\subsection{Experimental design}

We studied the simulation experiments over $24 \mathrm{~h}$ under different temperature $\left(20^{\circ} \mathrm{C}, 25^{\circ} \mathrm{C}\right.$ and $30^{\circ} \mathrm{C}$ ), loading density $\left(200,300\right.$ of $\left.400 \mathrm{~g} \mathrm{~L}^{-1}\right)$ and fry body weight using different water medium (river, pond and tubewell). Fingerlings $(6 \mathrm{~kg})$ were placed into each aluminum vessel $(30 \mathrm{~L})$ filled with different water at a different loading density for incubation. $0.9 \% \mathrm{NaCl}$ solution (table salt $9 \mathrm{~g} \mathrm{~L}^{-1}$ ) was used as bathing saline water before transportation. Water temperature was controlled and kept constant by the aquarium cooler.

\subsection{Sampling, measurement and analysis}

Measurements of $\mathrm{pH}, \mathrm{DO}$ and $p \mathrm{CO}_{2}$ were carried out 6 times per day (4h interval) for 3 replications. Water $\mathrm{pH}$ and dissolved oxygen (DO) were measured using a $\mathrm{pH}$ meter ORION 4 STAR and calibrated with NIST (NBS)-scaled buffer solutions (Mettler pH 6.865 and 4.008 buffers). Carbon dioxide concentrations were calculated with the program CO2SYS [28] using pH, alkalinity, salinity and temperature data sets. Oxygen consumption was calculated using this formula:

$$
\text { Oxygen consumption }(\mathrm{OC})=\frac{\text { Initial DO }- \text { Final DO }}{\text { Weight of fry }(\mathrm{kg}) \times \text { time }(\mathrm{h})}
$$

\subsection{Statistical analysis}

The mean values, standard deviation (SD) and correlation coefficient $(r)$ were analyzed by using statistical software. We performed an ANOVA (two-factor without replication) to analyze the variances with 0.05 level of significance.

\section{Results}

\subsection{Relationship between $\mathrm{pH}$ and $\mathrm{pCO}_{2}$}

During $24 \mathrm{~h}$ incubation experiment, we found significant differences between initial and final values of $p \mathrm{CO}_{2}$ and $\mathrm{pH}$. With increasing $p \mathrm{CO}_{2}$ levels, $\mathrm{pH}$ values also decreased in incubation sample water. $\mathrm{pH}$ and $p \mathrm{CO}_{2}$ varied from 8.4 to 6.5 and $175 \sim 20017 \mathrm{ppm}$ respectively. We found strong negative correlation between $\mathrm{pH}$ and $\mathrm{pCO}_{2}(r=-0.89 ; t$-test, $\mathrm{n}=18 ; P=0.0019)$; and there were no significant differences among 3 replicates $(P>0.05)$. Due to fish seeds (fry) respiration, $p \mathrm{CO}_{2}$ levels increased and $\mathrm{pH}$ level decreased significantly in sample water (Figs. 1 and 2). 


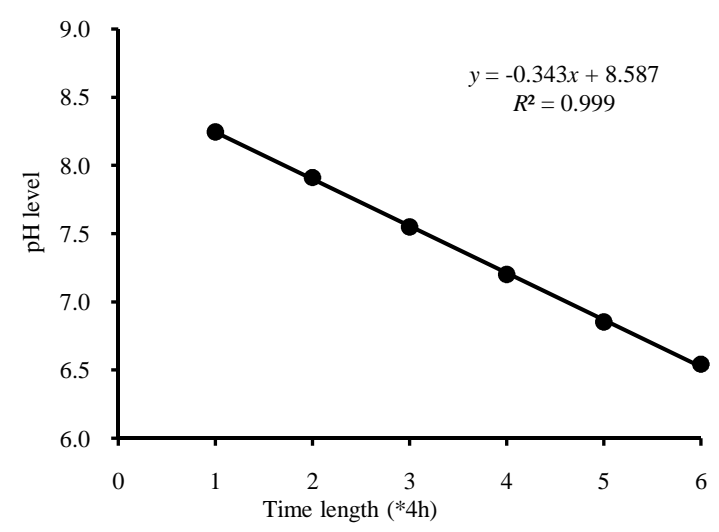

Fig. 1. Decreasing $\mathrm{pH}$ level in water with time length due to fish seeds respiration.

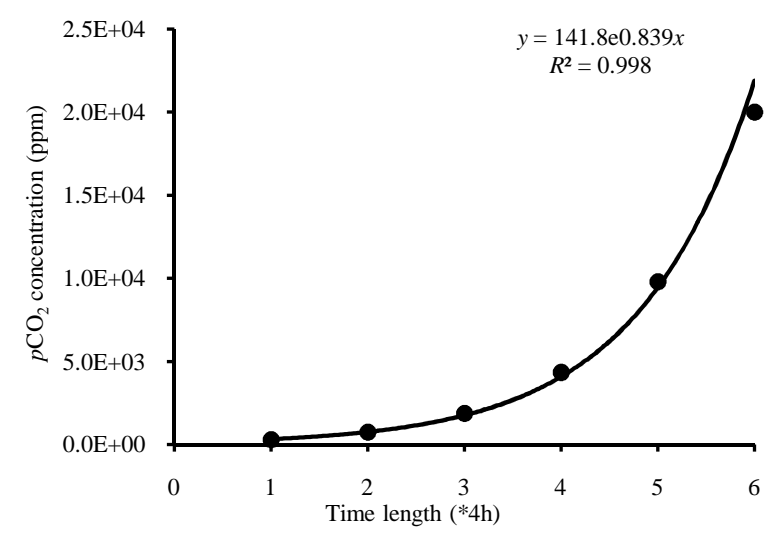

Fig. 2. Increasing $p \mathrm{CO}_{2}$ concentration in water with time length due to fish seeds respiration.

\subsection{Effect of loading density}

Assessment of loading density exposed that fingerlings stocked at $400 \mathrm{~g} \mathrm{~L}^{-1}$ had a higher mortality rate (river water $82 \%$, pond water $70 \%$ and tubewell water $67.5 \%$ ) than those loaded at $200 \mathrm{~g} \mathrm{~L}^{-1}$ and $300 \mathrm{~g} \mathrm{~L}^{-1}$; and lower level of mortality was observed at 200 and $300 \mathrm{~g} \mathrm{~L}^{-1}$ after simulated transport incubation experiment (Table 1). Whereas only a few fingerlings died at all densities after $4 \mathrm{~h}$ but mortality rates significantly increased with time scale and loading density under different water medium (ANOVA, HSD; $P<0.05$ ). Mortality rates were higher in river water than pond and tubewell water medium ('Rank and Percentile' and 'ANOVA; $P=0.0001$ ). The total mortality rates were just about four times higher after $24 \mathrm{~h}$ transport time duration at $400 \mathrm{~g} \mathrm{~L}^{-1}$ that at 200 and $300 \mathrm{~g} \mathrm{~L}^{-1}$. 
Table 1. Mortality rate of fish seeds (Labeo rohita) at different loading densities under different water medium during over $24 \mathrm{~h}$ simulated transport incubation experiment.

\begin{tabular}{|c|c|c|c|c|c|c|c|c|c|}
\hline \multirow{3}{*}{$\begin{array}{l}\text { Time } \\
\text { scale } \\
\text { (h) }\end{array}$} & \multicolumn{9}{|c|}{ Mortality rate (\%) at different loading density } \\
\hline & \multicolumn{3}{|c|}{$200\left(\mathrm{~g} \mathrm{~L}^{-1}\right)$} & \multicolumn{3}{|c|}{$300\left(\mathrm{~g} \mathrm{~L}^{-1}\right)$} & \multicolumn{3}{|c|}{$400\left(\mathrm{~g} \mathrm{~L}^{-1}\right)$} \\
\hline & $\mathrm{Tw}$ & $\mathrm{Pw}$ & $\mathrm{Rw}$ & $\mathrm{Tw}$ & $\mathrm{Pw}$ & $\mathrm{Rw}$ & $\mathrm{Tw}$ & $\mathrm{Pw}$ & $\mathrm{Rw}$ \\
\hline 04 & $0.00 \pm 0.0$ & $1.00 \pm 0.0$ & $2.00 \pm 0.0$ & $0.00 \pm 0.0$ & $2.00 \pm 0.0$ & $3.00 \pm 0.1$ & $2.00 \pm 0.0$ & $3.00 \pm 0.1$ & $4.50 \pm 0.1$ \\
\hline 08 & $2.50 \pm 0.1$ & $5.50 \pm 0.2$ & $8.00 \pm 0.1$ & $3.50 \pm 0.2$ & $6.00 \pm 0.1$ & $10.0 \pm 0.3$ & $8.00 \pm 0.2$ & $12.0 \pm 0.2$ & $18.0 \pm 0.3$ \\
\hline 12 & $8.50 \pm 0.0$ & $11.0 \pm 0.1$ & $20.0 \pm 0.2$ & $7.00 \pm 0.4$ & $15.0 \pm 0.3$ & $23.0 \pm 0.3$ & $34.0 \pm 0.1$ & $37.0 \pm 0.3$ & $42.0 \pm 0.2$ \\
\hline 16 & $17.0 \pm 0.1$ & $24.0 \pm 0.3$ & $28.5 \pm 0.3$ & $24.0 \pm 0.4$ & $27.5 \pm 0.5$ & $36.0 \pm 0.1$ & $52.0 \pm 0.3$ & $58.0 \pm 0.1$ & $69.0 \pm 0.1$ \\
\hline 20 & $19.0 \pm 0.3$ & $26.5 \pm 0.5$ & $30.0 \pm 0.3$ & $25.0 \pm 0.3$ & $31.0 \pm 0.2$ & $39.5 \pm 0.2$ & $61.0 \pm 0.2$ & $64.5 \pm 0.4$ & $75.0 \pm 0.6$ \\
\hline 24 & $22.5 \pm 0.2$ & $31.0 \pm 0.2$ & $37.5 \pm 0.4$ & $29.0 \pm 0.2$ & $35.0 \pm 0.1$ & $45.0 \pm 0.2$ & $67.5 \pm 0.5$ & $70.0 \pm 0.3$ & $82.0 \pm 0.5$ \\
\hline
\end{tabular}

$[\mathrm{Rw}=$ River water; $\mathrm{Pw}=$ Pond water; Tw $=$ Tubewell water $]$.

The mean values $(\%)$ and standard deviations $( \pm \mathrm{SD})$ are specified. Mortality rates $(\%)$ are significantly different (ANOVA, HSD; $P<0.05$ ) with loading density and time scale under different water medium.

\subsection{Effect of saline water bath}

Significant effect obtained when spawns and fry were bathed with saline water $(0.9 \%$ $\mathrm{NaCl}$ solution) before transportation. After $24 \mathrm{~h}$ observation we found $42.5 \%$ mortally from control group without saline water bath, whereas with saline water bath were $20.5 \%$. So, there was significant difference between with and without saline water bath $(P=$ $0.003 ; r=+0.95)$; and mortality rate decreased (22\%) if the spawns are bathed in saline water before transportation (Fig. 3).

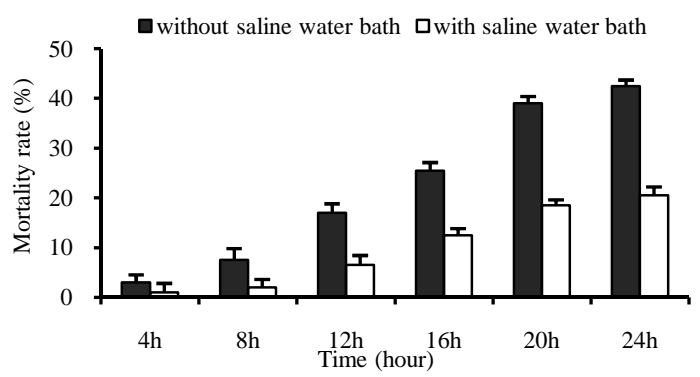

Fig. 3. Showing comparison of mortality rate between with and without saline water bath.

\subsection{Effect of temperature with relation to fry size and oxygen consumption}

There was significant difference between fry weight and oxygen consumption at different level of temperature. Oxygen consumption rate increased significantly $(P=0.008 ; r=$ 
$+0.92)$ with increasing temperature (Fig. 4$)$ and decreased significantly $(P=0.008 ; r=-$ 0.91 ) with increasing fry body weight.

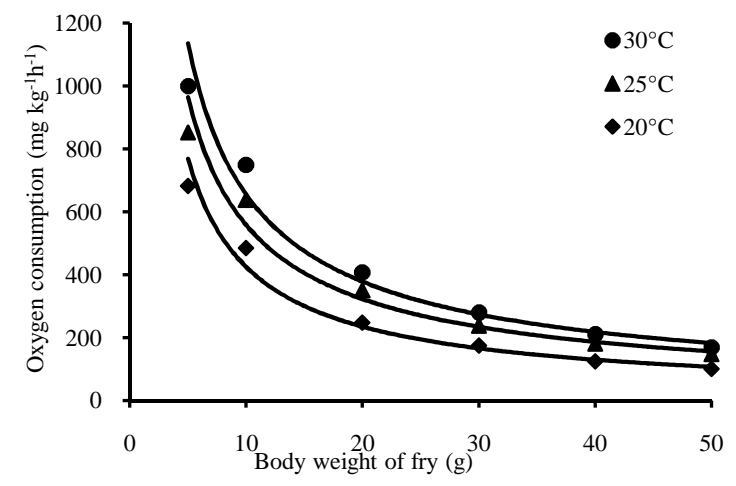

Fig. 4. Graphical representation of oxygen consumption of fish seeds at different water temperature.

We found oxygen requirement of fry ranges from $100 \sim 1000 \mathrm{mg} \mathrm{kg}^{-1} \mathrm{~h}^{-1}$ and it's depends on fry size. In case of $5 \mathrm{~g}$ weight of Labeo rohita fry, oxygen consumption rate were 682,852 and $1000 \mathrm{mg} \mathrm{kg}^{-1} \mathrm{~h}^{-1}$ at $20^{\circ} \mathrm{C}, 25^{\circ} \mathrm{C}$ and $30^{\circ} \mathrm{C}$ respectively; whereas 100,147 and $170 \mathrm{mg} \mathrm{kg}^{-1} \mathrm{~h}^{-1}$ oxygen were consume by $50 \mathrm{~g}$ weight of fry.

\section{Discussion}

Fish seed transportation is done in traditional method, using different types of containers with water (open system). Oxygenation is done by frequent splashing of water. Fry are also transported in polythene bag with water supplied with oxygen (closed system). Various types of transports are used; from shoulder load up to rickshaw van, bicycle, motorized vehicles and railway, depending on the distance where to carry the seed. Poor fry traders are mainly transported by bicycle and walking by foot. For longer distance transportation, seeds are transported under oxygenated condition. The period of conditioning should depend on the size and distance of transport. About 6 hours of conditioning is required before fry should be packed for transportation [29]. Catla fry need 48 to 72 hours of conditioning. Empty intestine fish fry consume less oxygen than full intestine fry [30]. The vital key factor in transporting fry is providing an adequate level of dissolved oxygen [7]. Oxygen consumption depends on their tolerance to stress, water temperature, $\mathrm{pH}$, and concentrations of $\mathrm{pCO}_{2}$ and metabolic products such as urea and ammonia. Avoiding urea and ammonia level, intestine of fry should be discouraged and adapted to strong stress before transport.

Mortality rate of fish seeds increased gradually with increasing loading density and also depends on time duration of transportation. Depending on the distance and other factors, the fingerlings may remain in the transport vessels for 1-6 h. Labeo rohita fry are 
relatively sensitive to the stress of transport; as a result there is a high mortality among transported fry [31]. We used different types of water in containers as a transport medium and found higher mortality rates in river water than pond and tubewell water medium (Table 1). River water generally loaded with organic, inorganic and microbes and it is not suitable for fish larvae. Among which mortality rate and the related physico-chemical variation in the river water are higher than that of pond water. Again if transportation is carried out in little $\mathrm{O}_{2}$ content tubewell water, this mortality could decrease without any addition. We observed $82 \%$ mortality at $400 \mathrm{~g} \mathrm{~L}^{-1}$ in river water medium and that were four times higher at $200 \mathrm{~g} \mathrm{~L}^{-1}$ loading density after $24 \mathrm{~h}$ simulated transport incubation experiment. 83-92\% mortality have been observed in carps, largemouth bass Micropterus salmoides, freshwater drum Aplodinotus grunniens and striped bass Morone saxatilis [3134]. Lower level mortality may possibly be explained by the quality of the water remaining within the tolerance limit and the less immediate effects of stress at a lifethreatening level during transport $[35,36]$ and they reported $4 \sim 12 \%$ mortality in Labeo rohita fingerlings. $4 \sim 7 \%$ immediate mortality in freshwater drum when transported for 6 - $12 \mathrm{~h}$ by truck at 60 and $120 \mathrm{~g} \mathrm{~L}^{-1}$ loading densities, respectively [33].

The addition of sodium chloride $(\mathrm{NaCl})$ in transport water medium can decrease handling stress and delayed mortality of fish fry. The salt water has therapeutic value and can prevent the transmission of fresh water disease from one fish to another and at the same time reduce the bacterial growth within the water. Many chemical additives have been used to transport fish seed but there is very few evidence to support claims of any real benefit. However, table salt $(\mathrm{NaCl})$ is biologically important for osmoregulation and metabolic function of fish fry. Previously, sodium chloride ( $0.8 \%$ table salt) was used to reduce handling stress in channel catfish [37]. We found a good result using table salt $(0.9 \% \mathrm{NaCl})$; mortality rate decreased $(22 \%)$ after bathing fry (Labeo rohita) with saline water before transportation. Before transportation, saline water bath can be performed to reduce mortality rate of carp fry [38]. Some of the fishes like as carp, striped bass, tilapias that tolerate wide ranges of salt in the water medium, can benefit from this method. Several studies suggested 0.1 to $0.3 \%$ [39], 0.2\% [40], 1\% [41] addition of table salt concentration can provide good results when transporting fish fry. Different salt concentrations such as $0.3 \%$ for low temperature, $0.5 \%$ for medium temperatures and $0.7 \%$ for $25-26^{\circ} \mathrm{C}$ water temperatures were used to decrease mortality rate of fry [42]. But on the other hand, no favorable influence of salt addition was demonstrated during fish transportation [43-45]. Local rice beer (prepared from fermented rice) was added (1 $\mathrm{ml}$ per packet) in the transportation package water for better survival and less mortality during transportation [46]. Farmers reported that before packaging of transport vessel, about $100 \mathrm{~g}$ of red soil per hundy (30 ml water) or cow dung slurry (10:1) are significantly effective against disease contamination.

Generally major carps are eurythermal [47] and on the basis of the relationship between oxygen consumption and acclimation temperature, optimum temperatures can be estimated [13]. Oxygen consumption depends habitually on fry species, fry size, physiological condition of individual and on a number of environmental factors. The vital 
factors of oxygen consumption by fish seeds during transportation depends on relation with oxygen metabolism, fry weight, loading density and water temperature. A large fingerling consumes less oxygen per unit weight than does a small one [7]. We found similar statement from our experiment, $100 \sim 170 \mathrm{mg} \mathrm{kg}^{-1} \mathrm{~h}^{-1}$ oxygen consumed by $50 \mathrm{~g}$ weight of fry and $682 \sim 1000 \mathrm{mg} \mathrm{kg}^{-1} \mathrm{~h}^{-1}$ by $5 \mathrm{~g}$ weight of Labeo rohita fry at deferent temperature. If the water temperature increases by $10^{\circ} \mathrm{C}$ (e.g., from 10 to $20^{\circ} \mathrm{C}$ ), oxygen consumption is about doubled; so loading density should be reduced [48]. The high loading density increases ammonia levels when dissolved oxygen is low [49]. Our experiment stated that increasing water temperature enhanced oxygen consumption rate of fry significantly $(P=0.008 ; r=+0.92)$. Similar statement, increasing water temperature accelerates the metabolic rate and oxygen consumption [50]. In warm weather mortality rate is enhanced due to quick warming up of the container, which first of all affect the rate of oxygen consumption by the fish seeds, and thereby the physio-chemical condition of the water. In such cases, heavy mortality occurred, if the traders fail to replace the water, or keep the water cool by constantly keeping the body of the receptacles wet.

These results indicate that rate of mortality of fish seeds during our traditional transportation system can decrease by following simple procedures. Improvement of conditioning method before transportation can be beneficial for fry survival. Also avoiding high loading density and frequently splashing water for oxygen supply keeps the fry in good condition. Changing water after $1 \sim 1.5 \mathrm{~h}$ during transportation can reduce fry death due to accumulation of toxic wastes. Seeds can be bathed in saline water before transportation to reduce disease and bacterial growth in the transport water. For keeping temperature cool earthen container can be used and tubewell water is good as a medium for long distance transportation.

\section{Acknowledgements}

The authors are grateful to Anando Matshaw Hatchery, Rajshahi, Bangladesh for providing ponds for conditioning and simulation experimental purposes. Authors are thankful to Hatchery Officers, Rajshahi and Puthia Matshaw Beej Utpadan Khamar, Bangladesh; Fish seed Traders, Fishermen of study area for their kind cooperation and constructive suggestions, both of which improved the manuscript. Special thanks to Mr. Pramod Kumar Chumun for his help during the manuscript write-up.

\section{References}

1. T. Das, A. K. Pal, S. K. Chakraborty, S. M. Manusha, N. P. Sahu, and S. C. Mukherjee, J. Therm. Biol. 30, 378 (2005). http://dx.doi.org/10.1016/j.jtherbio.2005.03.001

2. R. K. Singh, V. R. Vartak, A. K. Balange, and M. M. Ghughuskar, Aquaculture. 235, 297 (2004). http://dx.doi.org/10.1016/j.aquaculture.2003.12.011

3. T. J. Abraham, S. K. Sil and P. Vineetha, Indian J. Fish. 57, 41 (2010).

4. T. M. Chao and L. C. Lim, Singap. J. Prim. Ind. 19, 78 (1991).

5. M. N. Duray, C. B. Estudillo, and L. G. Alpasan, Aquaculture. 150, 63 (1997). http://dx.doi.org/10.1016/S0044-8486(96)01467-6 
6. J. V. Juario, J. R. Silapan, and L. L. Silapan Jr., Proceedings of the Seminar-Workshop on Breeding and Seed Production of Cultured Finfishes of the Philippines. (SEAFDEC/AQD, Tigbauan, Iloilo, Philippines, 4-5 May 1993) p. 132.

7. R. Berka, EIFAC Tech. Pap. 48, 52 (1986).

8. F. G. Ayson, M. M. Parazo, and D. M. Reyes Jr., J. Appl. Ichthyol. 6, 161 (1990). http://dx.doi.org/10.1111/j.1439-0426.1990.tb00574.x

9. F. C. Gou, L. H. Teo, and T. W. Chen, Aquacult. Res. 26, 265 (1995). http://dx.doi.org/10.1111/j.1365-2109.1995.tb00911.x

10. H. Kaiser and N. Vine, Aquar. Sci. Conserv. 2, 1 (1998). http://dx.doi.org/10.1023/A:1009683325104

11. T. Das, A. K. Pal, S. K. Chakraborty, S. M. Manush, N. Chatterjee, and S. C. Mukherjee, J. Therm. Biol. 23, 157 (2004). http://dx.doi.org/10.1016/j.jtherbio.2004.02.001

12. S. M. Manush, A. K. Pal, N. Chatterjee, T. Das, and S. C. Mukherjee, J. Therm. Biol. 29, 15 (2004). http://dx.doi.org/10.1016/j.jtherbio.2003.11.005

13. J. Kita, S. Tsuchida, and T. Setoguma, Mar. Biol. 125, 467 (1996).

14. J. R. Brett, Fish Physiology. vol. VIII. Academic Press, London, pp. 599 (1979).

15. L. S. Smith, Fish Nutrition. Academic Press, New York, USA (1998).

16. C. Burel, P. L. Ruyet, F. Gaumet, A. L. Roux, A. Severe, and G. Boeuf, J. Fish Biol. 49, 678 (1996). http://dx.doi.org/10.1111/j.1095-8649.1996.tb00064.x

17. A. M. Phillips and D. R. Brockway, Prog. Fish-Cult. 16, 65 (1954). http://dx.doi.org/10.1577/1548-8659(1954)16[65:EOSWTA]2.0.CO;2

18. K. S. Norris, F. Brocato, F. Calandrino, and W. N. Mc Farland, Calif. Fish Game. 46, 5 (1960).

19. C. M. Nemoto, Prog. Fish-Cult. 19, 147 (1957). http://dx.doi.org/10.1577/1548-8659(1957)19[147:EWMFAT]2.0.CO;2

20. W. N. Mc Farland, Calif. Fish Game. 46, 407 (1960).

21. V. S. Durve and S. K. Dharma Raja, I. J. Mar. Biol. Assoc. India. 8, 28 (1966).

22. G. L. Smith, H. J. Schoonbee, and W. T. Barham, S. Afr. J. Sci. 73, 351 (1977).

23. T. Murai, J. W. Andrews, and J. W. Muller, Prog. Fish. Cult. 41, 27 (1979). http://dx.doi.org/10.1577/1548-8659(1979)41[27:FAS|2.0.CO;2

24. N. Takashima, H. Kasai, H. Asakawa, and Y. Yamada, Suisan Zoshoku. 30, 48 (1982).

25. W. N. Mc Farland and K. S. Norris, Calif. Fish Game. 44, 291 (1958).

26. V. S. Durve, Indian J. Fish. 13, 158 (1970).

27. V. S. Durve, Aquaculture. 5, 53 (1975). http://dx.doi.org/10.1016/0044-8486(75)90017-4

28. E. Lewis and D. W. R. Wallace, CO2SYS-Program (1998).

29. K. H. Alikunhi, Fish Bull. Indian Coun. Agric. Res. 20, 144 (1957).

30. N. Jagannadhan, J. Bombay nat. Hist. Soc. 47, 315 (1947).

31. D. J. Lewis, G. D. Wood, and R. Gregory, Trading the silver seed (University Press Limited. Dhaka, Bangladesh, 1996).

32. G. J. Carmichael, J. R. Tomasso, B. A. Simco, and K. B. Davis, Trans. Am. Fish. Soc. 113, 778 (1984). http://dx.doi.org/10.1577/1548-8659(1984)113<778:CAAOSA>2.0.CO;2

33. D. L. Johnson and M. T. Metcalf, Trans. Am. Fish. Soc. 111, 58 (1982). http://dx.doi.org/10.1577/1548-8659(1982)111<58:CACOFD>2.0.CO;2

34. P. M. Mazik, B. A. Simco, and N. C. Parker, Trans. Am. Fish. Soc. 120, 121 (1991). http://dx.doi.org/10.1577/1548-8659(1991)120<0121:IOWHAS >2.3.CO;2

35. M. Hasan and A. N. Bart, Asia-Pacific J. Rural Dev. 16, 97 (2006).

36. M. Hasan and A. N. Bart, Fish Physiol Biochem. 33, 241 (2007). http://dx.doi.org/10.1007/s10695-007-9136-7

37. W. A. Wurts, World Aquaculture. 26, 80 (1995). http://dx.doi.org/10.1111/j.1749-7345.1995.tb00212.x

38. M. R. Nabi and M. A. Hossain, Raj. Fish Bull. 1, 51 (1983).

39. H. K. Dupree and J. V. Huner, Washington, D.C., U.S. Fish and Wildlife Service, p. 165 (1984).

40. S. K. Johnson, Aquacult. Mag. 5, 20 (1979).

41. N. A. Powell, Progr. Fish-Cult. 32, 18 (1970). 
http://dx.doi.org/10.1577/1548-8640(1970)32[18:SBIAS]2.0.CO;2

42. J. Hattingh, F. Le Roux Fourie, and J. H. J. van Vuren, J. Fish Biol. 7, 447 (1975). http://dx.doi.org/10.1111/j.1095-8649.1975.tb04619.x

43. D. F. Amend, T. R. Croy, B. A. Goven, K. A. Johnson, and D. H. McCarthy, Transactions of the American Fisheries Society. 111, 603 (1982). http://dx.doi.org/10.1577/1548-8659(1982)111<603:TOFICS >2.0.CO;2

44. O. Pecha, R. Berka, and J. Kouril, Ser. Metod. VURH Vodnany. 10, 16 (1983).

45. G. J. Carmichael, The Prog Fish-Cult. 46, 111 (1984). http://dx.doi.org/10.1577/1548-8640(1984)46<111:LDTTOI>2.0.CO;2

46. A. Das, B. Debnath, T. G. Choudhury, D. Roy, B. Saha and A. Paul, Indian J. Traditional Knowledge 12, 66 (2013).

47. H. M. Kasim, Thermal Ecology. BRNS, DAE (Mumbai Publishers, Mumbai, 2002) p. 222.

48. R. G. Piper, I. B. McElwain, L. E. Orme, J. P. McCraren, L. G. Fowler, and J. R. Leonard, Fish and Wildlife Service, Washington D.C. (1982) p. 517.

49. J. C. Merkens and K. M. Downing, Ann. Appl. Biol. 45, 521 (1957). http://dx.doi.org/10.1111/j.1744-7348.1957.tb05891.x

50. K. P. Biswas, A Text Book of Fish, Fisheries and Technology (Narendra Publishing House, Delh, 1990) p. 531. 